\title{
Teacher Education Programmes at Alexandria University with reference to Tuning Methodology*
}

\author{
Alsaeed Alshamy**
}

doi: 10.18543/tjhe-3(2)-2016pp281-317

\begin{abstract}
The study aims at using the outcomes of Tuning Africa Project - I to propose implications for policy and practice for enhancing the quality of Teacher Education Programmes in Egyptian higher education. It investigates the views of different stakeholders - academics, students, graduates and employers - who relate to three faculties in charge of Teacher Education at Alexandria University. The study focuses on the generic competences and the key subject-specific competences which future teachers should be acquainted with. The data have been collected through questionnaires administered to 384 participants and through semi-structured interviews with 10 academics. The main findings show that, across all different stakeholders, there are significant gaps for both generic and subject-specific competences between what is deemed important and what is deemed as the level of achievement at Alexandria University. The average ranking for both generic and subject-specific competences was 3.75 in terms of importance but only 2.54 in terms of achievement. This is an indication that effort and intentional strategies needed to be put in place to minimize the gaps of the relevant Teacher Education Programmes. This calls for a paradigm shift from input and staff-centered programmes to output and student oriented ones. In order to achieve such a paradigm shift, several actions concerning policy and practice should be promoted. Among them, the study proposes changing the regulations of existing programmes; revising programmes in order to allow inclusion of the Tuning determined generic and subject-specific competences. The study further proposes raising awareness about the importance of competencebased learning among academics, students, graduates, employers and the society at large as well as involving all stakeholders in the process of curriculum design and quality enhancement. All these are potential in promoting capacity building and

* This work was carried out at Deusto International Tuning Academy (DITA) at the University of Deusto, Bilbao, Spain, and was financially supported by DITA Short-Term Visit Scholarship. It was conducted between March 2014 and August 2015. The Author would like to thank Tuning Academy for such kind support and would also like to thank participants from Alexandria University for their time and precious reflections.

** Saeed Alshamy (saeed.alshamy@edu.alexu.edu.eg), $\mathrm{PhD}$ in Education, is an assistant professor at Foundations of Education Department, Faculty of Education, Alexandria University, Egypt. More details are provided at the end this article.
\end{abstract}


training for academics who are equipped to incorporate new competences in the existing programmes/courses. Such academics will be able to initiate new courses with commonly agreed structures; they will be able to incorporate the needed competences in such a way that comparability and equivalence of learning outcomes between Alexandria University and other African universities become possible.

Keywords: teacher education; higher education; Alexandria University; Tuning Africa Project I; competence-based learning; generic competences; subject-specific competences; internationalization; regionalization; policy learning.

\section{Introduction}

This paper starts with a brief introduction, which sets out the research problem and the related research questions. Subsequently, a brief overview of Tuning approach and Tuning Africa Project - I between internationalization and regionalization is presented, followed by a brief articulation on Competence-based Learning. This leads to a section on policy learning vs. policy borrowing approach. The research design is, then, discussed including: the methodological stance and approach and methods of data collection. The results of the empirical enquiry are reported, followed by discussion, concluding remarks and implications of the study for policy and practice.

\section{Rationale for the study}

The recognition that higher education is a major driver of economic competitiveness in the global economy has made its quality ever more important, contributing to social and economic development in four main ways. Firstly, it makes an economic contribution through the formation of human capital, primarily by training a qualified and adaptable labour force. Secondly, it builds the knowledge base through research and development. A third way is through the dissemination and use of knowledge through interactions, such as consultancy, with the wider economy. Fourth, it contributes to the maintenance of knowledge via inter-generational storage and transfer. ${ }^{1}$ However, there are multiple

${ }^{1}$ OECD, "Tertiary Education for the Knowledge Society: OECD Thematic Review of Tertiary Education: Synthesis Report”, (2008), Accessed April, 12014 , http://oecd-conferenceteks.iscte.pt/downloads/OECD_overview.pdf. 
challenges facing higher education in Egypt, most notably issues of finance, quality and governance, reinforced by massive numbers of students and demographic pressures for more expansion, which are detrimental to the quality of provision. ${ }^{2}$

Egypt's increasing population is accompanied by increasing unemployment rates as graduates' skills do not satisfy employers and market needs. Approximately 600,000 school and university graduates are competing over 200,000 jobs every year, ${ }^{3}$ which led to increasing unemployment rates reaching $12.8 \%$ in 2015, as indicated in Figure $1 .^{4}$

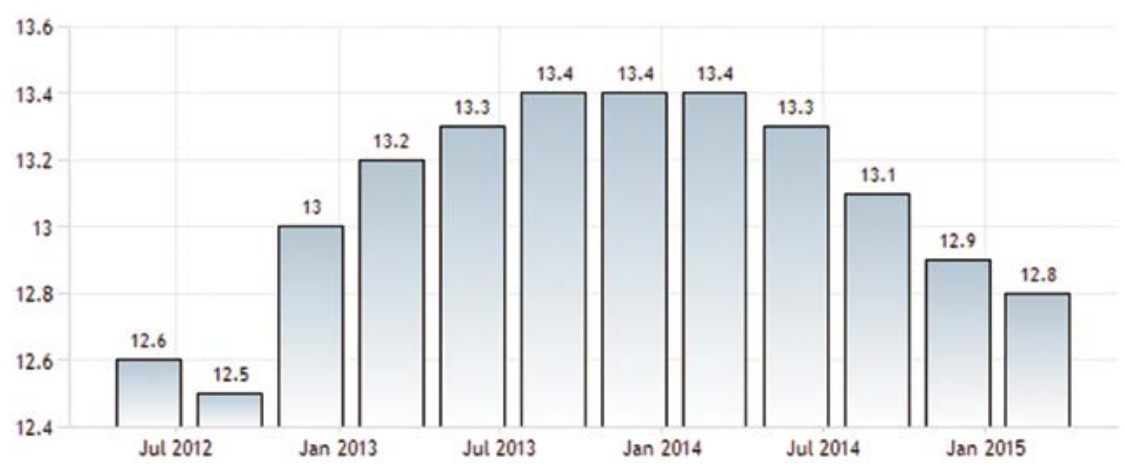

Source: CAPMAS. ${ }^{5}$

Figure 1

Unemployment rates in Egypt (2012-2015)

2 Alsaeed Alshamy, Quality, Finance and Governance in Egyptian higher Education: A Comparative Analysis (Berlin: LAP Lambert Academic Publishing, 2013), 6.

3 See: Ghada Amin, "Egypt Country Report: Policies and Mechanisms for Integration into the Workforce and Job Creation" (paper presented at the 2014 Ministerial Conference on Youth Employment: How to Improve, through Skills Development and Job Creation, Access to Africa's Youth to the World of Work, Abidjam, Côte d'Ivoire, July 21-23, 2014) and Amr Ezzat Salama, "Addressing the Challenges of the Education/Skills and Jobs Mismatch" (Education partnerships and work skills on the menu at ECOSOC, Coordination Segment Pane II Issue Note, New York, 10-12 July, 2012), accessed April, 1, 2014, http://www.un.org/en/ ecosoc/julyhls/pdf12/un_presentation-dr_amr_salama.pdf.

${ }^{4}$ Central Agency for Public Mobilization and Statistics (CAPMAS), Egypt Statistical Yearbook 2015 (Cairo: CAPMAS, 2015).

${ }^{5}$ Central Agency for Public Mobilization and Statistics (CAPMAS), Egypt Statistical Yearbook 2015 (Cairo: CAPMAS, 2015). 
The situation is made worse by skills mismatch as $15 \%$ of employers state that graduate specializations do not meet the requirements of the labour market and $30 \%$ of graduates believe their specializations are not relevant to the labour market. More than $60 \%$ of employees are not working in their specialization field. Only $21 \%$ of employers say there is a sort of cooperation between their organizations and educational institutions. 57\% of private enterprises indicate that training centres' facilities are not adequate to provide quality training. $60 \%$ believe that training programmes do not meet the needs of the labour market and that training centers are supply-driven rather than demand-driven. ${ }^{6}$

Skills mismatches are a structural labour market problem in North Africa, which can be illustrated using unemployment rates by educational attainment. The unemployment rates for persons with tertiary-level education are among the highest in the world, at $21.4 \%, 18.9 \%$ and $17.4 \%$ in 2010 in Algeria, Egypt and Morocco, respectively. In Algeria and Egypt, they are higher than for persons with primary or secondary education, pointing at a mismatch between the supply of and demand for skills and education. In most advanced economies, persons with higher levels of education are less likely to be unemployed, but this does not seem to apply to North African economies, as prospects of finding jobs for those having completed tertiary education are unpleasant. ${ }^{7}$

The mismatch continues as those challenges facing education in Egypt are accompanied by massive numbers of students and demographic pressures for more expansion, which are detrimental to the quality of provision and thus put pressures on all aspects of social and economic development. Therefore, the impact of providing adequate and quality schooling and education puts teacher education on the front line with health services. Thus, there is a crucial need for educational reform and most importantly for improving Teacher Education programmes, which are the main focus of this paper.

However, Egypt is not alone in facing such challenges as many countries of Middle East and North Africa face similar challenges in their educational systems, skills mismatch and high rates of youth unemployment. As a result, in virtually every country in the continent, committees and reports recommend the review and modernisation of the existing curricula with a broadening of the view of the teacher education curriculum. Many such

6 Salama, "Education/Skills and Jobs Mismatch."

7 International Labour Organization, Global Employment Trends for Youth 2013: A Generation at Risk (GENEVA: ILO Cataloguing in Publication Data, 2013). 
reports emphasise the need for teachers to acquire skills in analysis and reflection and to achieve greater articulation / integration between theory and practice. Some people stress the need to give greater value and relevance to teaching practice while others, in consonant with the Harmonisation and Tuning objectives, call for a more competence-based approach to teaching/ learning and assessment of quality. Yet others call for experimentation with more diversified types of professional development appropriate to a competence-based approach. ${ }^{8}$

Several national, regional, continental and international transformative initiatives took place in the African Higher Education system, among which is the African Higher Education Harmonization and Tuning Project, which is part of the Africa-EU strategic partnership. The Tuning Africa Project - I (2012-2014) ended up with several findings, most importantly among them are the two lists of generic competences and key subject-specific competences for which future teachers should be acquainted with.

Building on the outcomes of Tuning Africa Project - I, this paper aimed at investigating the views of different stakeholders - academics, students, recent graduates and employers - of the three faculties (Faculty of Education, Faculty of Kindergarten and Faculty of Specific Education) in charge of Teacher Education at Alexandria University. The investigation focused on the generic competences and the key subject-specific competences for which future teachers should be acquainted with. It also aimed at exploring the stakeholders' views on the applicability of the generic competences and the key subject-specific competences and the possibility of reforming the higher education system by including such competences in the curriculum design, student assessment and evaluation systems.

There are multiple challenges facing higher education in Egypt, most notably: issues of finance, quality and governance, reinforced by massive numbers of students and demographic pressures for more expansion of the system. These challenges are detrimental to the quality of education provision. It is also recognized that Egypt is not alone in facing such problems. Therefore, the literature component of the study draws upon wider international experience of higher education reforms and examines their implications for Egypt.

The main aim of this study, therefore, is to investigate options for enhancing the quality of Teacher Education Programmes in Egyptian higher

${ }^{8}$ Matete Madiba et al., "Teacher Education," in Tuning and Harmonisation of Higher Education: The African Experience, eds. Charles Onana Awono et al., (Bilbao: University of Deusto, 2014), 315-374. 
education taking into consideration the societal context and the international experience of Tuning Africa Project - I through investigating the Tuning approach in the selected faculties at Alexandria University.

The aim is generally threefold:

- Designing common curriculum development frameworks to enable comparability and equivalence of learning outcomes between Alexandria University and other African universities

- Enhancing graduate mobility and employability

- Enhancing the quality of Teacher Education Programmes in Egyptian higher education

These objectives were developed into three research questions:

1. What are the perceptions of different stakeholders of Alexandria University on the generic competences which future teachers should be acquainted with?

2. What are the perceptions of different stakeholders of Alexandria University on the key subject-specific competences which future teachers should be acquainted with?

3. What are the foreseeable implications - according to study findings - for policy and practice to enhance the quality of Teacher Education Programmes in Egyptian higher education?

\section{Tuning Africa Project - I: internationalization and regionalization}

\section{III.1. Tuning Approach: philosophy and methodology}

Tuning is a methodology with clearly designed steps with a dynamic perspective that allows for adaptation to different contexts. It has a clear objective: to build compatible and comparable descriptions of degrees that are relevant to society and that are intensively focused on maintaining and improving quality. It explicitly calls for the process to value and preserve diversity among different countries. These requirements demand a collaborative approach, based on a consensus being developed by experts from backgrounds as varied as possible. These experts are expected to have the capacity to understand the negotiable and non-negotiable geographical realities as much as they must understand essential elements of the discipline 
and the degrees themselves. The Tuning methodology has four lines of work which help to organize discussion in specific subject areas: identifying relevant generic and subject specific competences and elaborating a metaprofile for the subject area; exploring how a mutually agreed cumulative credit system can facilitate degree comparability, graduate mobility and employability; exchanging good practices in approaches and techniques in teaching learning and assessment; and finally exploring how quality assurance frameworks can be used at programme level to enhance student learning. Accordingly, the European Union in collaboration with Tuning Academy had a series of partnership agreements with many regional bodies and organizations, so that the project could expand from the European level to a global scale, to include both: Africa, Australia, Europe, Latin America, Georgia, Kazakhstan, Russia, United States and Canada. There are other countries in the process of adopting Tuning methodology to join the "Tuning Family". 9

\section{III.2. Tuning Africa Project - I}

The African Higher Education system is undergoing a tremendous transformation process including a number of national, regional and continental initiatives. One of the most important transformation initiatives which links institutional, national, regional, continental and international endeavors is the African Higher Education Harmonization and Tuning Project, ${ }^{10}$ which is part of the Africa-EU strategic partnership. This project uses Tuning internationally established methodology to enhance degree comparability, graduate mobility

9 See: "Tuning Academy," http://tuningacademy.org/tuning-projects; “Tuning Academy Brochure," http://tuningacademy.org/wp-content/uploads/2015/01/Tuning_Academy_ brochure.pdf; The European Higher Education Area, "The Bologna Declaration of 19 June 1999: Joint declaration of the European Ministers of Education," (1999), accessed May 11, 2015, http://www.ehea.info/Uploads/Declarations/BOLOGNA_DECLARATION1.pdf; Berlin Communiqué, "Realising the European Higher Education Area" (Communiqué of the Conference of Ministers responsible for Higher Education, Berlin, 2003), accessed May 11, 2015, http://www.ehea.info/Uploads/Declarations/Berlin_Communique1.pdf; Julia Gonzalez and Robert Wagenaar, Tuning Educational Structures in Europe. Final Report: Pilot Project - Phase 1 (Bilbao: University of Deusto, 2003); Julia Gonzalez and Robert Wagenaar, Tuning Educational Structures in Europe. Universities' Contribution to the Bologna Process. Final Report: Pilot Project - Phase 2 (Bilbao: University of Deusto, 2005); and Julia Gonzalez and Robert Wagenaar, Tuning Educational Structures in Europe. 2nd ed. (Bilbao: University of Deusto, 2008).

${ }^{10}$ Madiba et al., "Teacher Education,” 191. 
and employability in five subject areas: Medicine, Teacher Education, Agriculture, Mechanical Engineering and Civil Engineering. ${ }^{11}$

Tuning Africa Project - I ended up with several findings, most importantly among which were the two lists of generic competences and key subject-specific competences which future teachers and graduates of the other four subject areas should be acquainted with. ${ }^{12}$ However, the main focus of this study was on Teacher Education. To validate the lists of competences, different stakeholders - academics, employers, students and graduates - were consulted on the degree of importance of those competences to future teachers and the level of achievement of the competences as a result of having completed a university degree.

\section{III.3. The main findings of Tuning Africa Project - I}

Overall, it was striking to note that for the generic competence "professionalism, ethical values and commitment to Ubuntu" (\#2) was placed in the top five most important competences across all subject areas while "environmental and economic consciousness" (\#13) was ranked among the least important competences by all groups.

As for Teacher Education subject specific competences, the main findings are summarized in Tables 1 and 2.

\section{Table 1}

The Highest and Lowest Rated Subject-Specific Competence in Terms of Importance

\begin{tabular}{|l|c|c|}
\cline { 2 - 3 } \multicolumn{1}{c|}{} & Highest & Lowest \\
\hline Academics & 1 & 13 \\
\hline Employers & 1 & 4 \\
\hline Students & 6 & 4 \\
\hline Graduates & 1 & 4 \\
\hline
\end{tabular}

${ }^{11}$ Karola Hahn and Damtew Teferra, "Tuning as Instrument of Systematic Higher Education Reform and Quality Enhancement: The Africa Experience," Tuning Journal for Higher Education 1 (2013): 127-163.

12 "Joint Africa-EU Strategy Tuning Seminars, Second General Meeting," Cape Town, 15-17 May (2012), accessed May 11, 2015, http://www.tuningafrica.org/images/stories/ documentos/documento_cape_town_ingles_final_para_colgar_final.pdf. 
Table 2

The Highest and Lowest Rated Subject-Specific Competence in Terms of Achievement

\begin{tabular}{|l|c|c|}
\cline { 2 - 3 } \multicolumn{1}{c|}{} & Highest & Lowest \\
\hline Academics & 1 & 13 \\
\hline Employers & 1 & 13 \\
\hline Students & 6 & 13 \\
\hline Graduates & 1 & 13 \\
\hline
\end{tabular}

The specific competences are:

- (\#1) Understanding of the subject(s) to be taught

- (\#4) Understanding of the local and international social, political, economic, cultural and environmental contexts of education

- (\#6) Understanding of the language(s) of instruction

- (\#13) Ability to develop one's own and learners' entrepreneurial skills

The above results imply that the academics, employers and graduates perceived a similarity both in the competences considered to be the most important and how successfully they were achieved. However, the students' data show a discrepancy between what they considered important and how well they felt it was achieved during their teacher education programs. The average ranking for all competences was 3.5 but achievement was 2.5. This finding implies that Teacher Education Programmes have gaps in instructional service delivery.

The respondents singled out as poorly achieved (1) professionalism, (2) ethics and values, (3) ability to understand and abide by the ethics values of the teaching profession and (4) ability to develop one's own and the learners' entrepreneurial skills. Yet these are some of the most important competences a teacher should possess. The most striking revelation in the findings is that academics rate "develop one's own and learners' entrepreneurial skills" (\#13) as both of least importance and least successfully achieved.

It is worth noting that, in all subject areas and among the different surveyed groups, significant gaps were found between what is deemed important and what is deemed as the level of achievement for both generic and specific competences. This is an indication that effort and intentional strategies need to be put in place to minimise the gaps. However, in order to validate the findings, further research is needed. Tuning Africa's final report 
suggested that further research is needed to validate the findings of that pilot project, ${ }^{13}$ which adds to the importance of the current study.

As stated in the introduction, the main focus in this study was on using findings of Tuning Africa Project - I to propose implications for policy and practice for enhancing the quality of Teacher Education Programmes in Egyptian higher education.

\section{Why competence-based learning?}

Thinking on competences has evolved in conceptual terms among higher education policymakers and different stakeholders in the last two decades, particularly with regard to generic competences, largely as a result of demands to make graduates better equipped for the rapidly changing world of work. Barriers to education attainment due to the rising costs of postsecondary education, coupled with unemployment of recent graduates, has made students, institutions, employers, and policymakers ask questions about how prepared students are for today's workplace and how much they are learning. The recognition that education in general and higher education in specific are major driver of economic competitiveness in the global economy and key to both national competitiveness and individual success has fueled a sense of urgency in overcoming affordability barriers to postsecondary education. Competence-based education and particularly, higher education are major determinants of the quality and employability of graduates. Competence-based Learning (CBL) is now increasingly being embraced as panacea for multiple pressing issues in higher education. It is often seen as having the potential to address accessibility, affordability, transparency, and improved learning outcomes, all of which relevant to graduates' employability and great strength to the workforce. ${ }^{14}$

\section{IV.1. CBL: a conceptual framework}

Before addressing the concept of Competence-based Learning, it is crucial to note that learning objectives/learning outcomes are sometimes

${ }^{13}$ Madiba et al., "Teacher Education,” 354-355.

${ }^{14}$ Patricia A. Book, "All Hands on Deck: Ten Lessons from Early Adopters of Competency-Based Education" (Boulder, CO: WICHE Cooperative for Educational Technologies (WCET), 2014). 
confused with competences. To remove this possible confusion, Tuning approach distinguishes between learning outcomes and competences.

The intended learning outcomes of a programme or unit of learning are formulated by academic staff. They may also be informed by the input of internal and external stakeholders, including - ideally - student representatives, but essentially they are what academics intend the students to learn. Learning outcomes are thus statements of what the teacher intends that the learner know, do, understand and be able to demonstrate after the completion of learning. Competences, on the other hand, are developed by students during the process of learning and represent a dynamic combination of knowledge, understanding, skills and abilities that the student builds on and develops during a period of study. Fostering competences is the object of educational programmes. Competences will be developed over the course of a number of units and assessed at different stages. ${ }^{15}$

Wagenaar added that competences should be understood as a dynamic representation of demonstrated knowledge, understanding/insight/ comprehension, (subject specific and generic) intellectual, practical and interpersonal skills and (ethical) values. They cover the whole spectrum of capabilities from pure theoretical and methodological knowledge to vocational knowledge/insight and from research abilities to practical abilities. Fostering these competences is the object of all educational programmes. Competences are formed during the process of learning by the student in succeeding course units or modules and are assessed at different stages. Competences are therefore owned by the student / learner. A learning outcome, on the other hand, is understood as a statement of what a learner is expected to know, understand and be able to demonstrate after completion of a process of learning. Learning outcomes indicate the level of competence that is desired and should be achieved. They are in other words the specifications of the results and outcomes of a learning process. The learning process again is based on an identified set of competences. Learning outcomes are distinguished in degree programme learning outcomes and module and/or unit learning outcomes. Learning outcomes are defined by academic staff preferably involving student representatives. Learning outcomes are therefore mostly owned by academic staff. ${ }^{16}$

15 Madiba et al., "Teacher Education," 345-346.

${ }^{16}$ Robert Wagenaar, "Competences and Learning Outcomes: a Panacea for Understanding the (New) Role of Higher Education?" Tuning Journal for Higher Education 1, no 2 (2014): 127-163. 
Klein-Collins summarizes important points about Competences versus learning outcomes and suggests that: 1) Competences are at a higher categorical level requiring students to process learning in a way that enables them to apply it in a variety of situations; 2) Competences are assessed at different levels that a student might be required to demonstrate depending on the educational level of the student; and, 3) Competences are considered more objectively measurable. ${ }^{17}$

Sanchez and Ruiz went in line with Klein-Collins and expanded the meaning of competences to imply good performance in diverse, authentic contexts based on the integration and activation of knowledge, rules and standards techniques, procedures, abilities and skills, attitudes and values. They ensure the notion that competences require students to process learning in a way that enables them to apply it in a variety of diverse and authentic situations. ${ }^{18}$

The notion of a competence-based approach to teacher education is not new and has been in use in teacher education in a number of countries for some considerable years. It has, however, often led to exaggeratedly long lists of competences to be achieved by the trainees. ${ }^{19}$

CBL is based on an analysis of the professional requirements that will help to define and prioritise the fundamental competences required for a given professional and/or specialty area. It is an approach to teaching and learning that necessarily starts from an academic and professional profile featuring all knowledge and competences that need to be developed by students pursuing a given course of studies. Their programme of studies must spell out the generic and specific competences desired, and distribute them over the entire degree course in question. This approach calls for a great deal of co-ordination and co-operation among faculty to contribute effectively and efficiently to the development of the academic-professional profile through each subject or course. ${ }^{20}$

The Main characteristics of CBL are summarized as follows: ${ }^{21}$

- CBL focuses on learning, pushing students toward mastery rather than a grade, and it brings needed emphasis on the assessment of learning.

${ }^{17}$ Rebecca Klein-Collins, "Competency-Based Degree Programs in The U.S.: Postsecondary Credentials for Measurable Student Learning and Performance" (Council on Adult and Experiential Learning, 2012).

18 Aurelio Villa Sánchez and Manuel Poblete Ruiz, (eds), Competence-based learning: A proposal for the assessment of generic competences (Bilbao: Deusto University Press, 2008).

${ }_{19}$ Madiba et al., "Teacher Education," 348.

${ }^{20}$ Sánchez and Ruiz, Competence-based learning, 34.

${ }^{21}$ Ibid. 
- CBL is student-centered approach.

- CBL focuses on what students know and can do rather than on what is taught.

- CBL consists in developing the necessary generic and specific competences pertaining to each profession.

- The aim is to endow students with scientific and technical knowledge, and to enable them to apply such knowledge in diverse complex contexts.

- To this end, knowledge is integrated along with attitudes and values in ways that are appropriate for each student's personal and professional life.

- CBL builds on a teaching-learning system that steadily develops students' autonomy and ability to learn how to learn.

- Last but not least, CBL is valued by employers as it better enables students to apply their knowledge.

\section{IV.2. CBL and employability}

One aspect of the CBL approach that has been criticized is its apparent emphasis on the workplace. There is concern that some academic objectives might be abandoned such as the overall humanistic education of students. Sanchez and Ruiz argue that this fear is unfounded, since CBL emphasizes individual growth and development as well as reflective thinking about what one learns and its application. Emphasis on humanism depends more on the way in which academics integrate these aspects into CBL than on the approach itself.

Competence-based learning is valued by employers because it better enables students to apply their knowledge. No one doubts that a university education should provide students with a good academic background, meaning good conceptual information and mastery of knowledge is expected to develop abilities and skills that can be applied to situations at work and in society that students will encounter when they finish their studies. The literature on this topic clearly suggest that having an education means not only having knowledge, but know-how, and learning to be and to live together, as memorably stated in the Delors Report on education.

Thus, the idea of competence includes the knowledge and know-how of certain subjects in different domains, as well as skills or abilities understood as practical or applied knowledge, and the personal attitudes and values that shape and guide people's conduct. As expressed in the 1988 World Higher Education 
Conference, there is a great need for life-long learning that will provide the competences that people must have if they are to contribute to the cultural, social and economic development of society ${ }^{22}$. The same aim was formulated in the Bologna Declaration to promote European citizens' employability. However, to avoid any misunderstandings it stipulated at the same time that this should be read in conjunction with the role higher education institutions have for personal development of the student as well as preparing them for citizenship. ${ }^{23}$

Linking the competences and learning outcomes gave a unique focus to the Tuning approach. The basic idea in Tuning was and is that the role of education is primarily to make the student / learner more competent as a result of a learning process. This is wider than knowledgeable and skilled, it also involves acting and 'how to be'. This is relevant for personal development, preparing for citizenship as well as positively affecting the learner's employability. ${ }^{24}$

\section{V. 'Policy learning' vs. 'policy borrowing' approach}

Given the rationale for investigating the wider international experience of higher education reform, including the Tuning Africa Project - I, it is clear that the study adopts a policy learning approach as it aims to support the development of tailored national policies rather than policies taken offthe-peg, as is the case with a policy borrowing approach which searches the international experience for examples of unique, transferable best practice. ${ }^{25}$

Adopting a policy learning approach served a broader range of purposes for the study, including using the comparative perspective to learn about the researcher's own country/system, learning from its history and context, illuminating its strengths as well as weaknesses, identifying common trends and pressures that affect all systems, identifying alternative policy options, testing their feasibility, understanding processes and dynamics of change and anticipating issues that possible options would raise and tailoring those policy options to suit national aims, needs and circumstances of the Egyptian context. ${ }^{26}$

${ }^{22}$ Ibid., 49.

${ }^{23}$ Wagenaar, "Competences and Learning Outcomes," 285.

${ }^{24}$ Ibid., 294.

${ }^{25}$ David Raffe, Policy borrowing or policy learning? How (not) to improve education systems (Centre for Educational Sociology: The University of Edinburgh. CES Briefing, No.57, 2011).

${ }^{26}$ See: David Raffe, Policy borrowing or policy learning?, 1-4. Borhene Chakroun, "What can we learn from policy learning," in Yearbook 2008. Policy Learning in Action 
The main outcome of this study is proposing common curriculum development frameworks to enable comparability and equivalence of learning outcomes between Alexandria University and other African universities. Through a careful process of policy learning, the paper draws implications for policy and practice, for the researcher's own university, other public universities in Egypt and for other countries having similar contexts.

\section{Research design}

\section{VI.1. The Methodological stance of the study}

The study is located within a broadly interpretive methodology, using a case study approach with questionnaires on both generic competences and key subject-specific ones and semi-structured interviews with different stakeholders of Alexandria University as the main methods of data collection, utilizing qualitative and quantitative data and approaches in all its components.

The interpretive methodology is viewed as suitable as it is believed that there are multiple interpretations of, and perspectives on, single events and situations (generic and subject-specific competences future teachers should be acquainted with) and that reality is multilayered and complex. An interpretive approach is primarily concerned with human understanding, interpretation and intersubjectivity, in essence lived experience or lived truth in its natural social context from the standpoint of individuals who are part of the ongoing action being investigated. ${ }^{27}$ However, precautions have been taken to overcome the risk of bias and subjectivity. ${ }^{28}$ These include data triangulation (through gathering multiple view points: academics, students, graduates and employers) and cross-referencing cases within the sample together with other precautions to enhance validity and reliability and ensure rigour of the findings that will be discussed later in the study.

(Turin: European Training Foundation, 2008), 11-18. David Phillips and Michele Schweisfurth, Comparative and International Education: An introduction to theory, method, and practice, $2^{\text {nd }}$ ed. (London: Continuum International Publishing Group, 2008).

${ }^{27}$ See: Noella Mackenzie and Sally Knipe, "Research Dilemmas: Paradigms, Methods and Methodology," Issues In Educational Research 16, n 2 (2006): 193-205 and Cohen et al., Research Methods in Education, $6^{\text {th }}$ ed. (London: Routledge, 2007).

${ }_{28}$ Norman K. Denzin and Yvonna S. Lincoln, Handbook of Qualitative Research (London: Sage, 2002). 


\section{VI.2. A case study approach}

This study is a detailed investigation of the views of different stakeholders - academics, students, graduates and employers - of three faculties at Alexandria University - as a case study - on the generic competences and the key subject-specific ones future teachers should be acquainted with. In addition to questionnaires administered to different stakeholders of Alexandria University, semi-structured interviews were conducted with academics with a view to an analysis of the context and processes involved in the phenomenon under study. The selected cases have enabled the researcher to develop detailed knowledge of the experience of participants on Teacher Education Programmes at Alexandria University and an examination of the strengths and weaknesses of existing systems, leading to an identification of implications for policy and practice for enhancing the quality of Teacher Education Programmes in Egyptian higher education.

A case study approach is viewed as suitable as case studies examine relationships between cause and effect but do not claim to establish a direct causal link. The strength of a case study is that it enables researchers to observe effects in real contexts, recognizing that context is a powerful determinant of both causes and effects. Another strength of the approach is that it provides fine-grain details ${ }^{29}$ as means for seeing situations through the eyes of participants. They are widely used in organizational studies in the social sciences. ${ }^{30}$ Lastly, the multiplicity of the variables and sources of evidence that characterise a case study inquiry are a holistic approach which investigates the case as a whole, recognizing its real-life context, rather than dealing with isolated factors. ${ }^{31}$

\subsection{Context: Teacher Education Programmes in Egypt}

Teacher Education Programmes have a long history since the establishment of the Modern State in Egypt (19 ${ }^{\text {th }}$ Century) till present. It is worth noting that every educational reform agenda included reforming Teacher Education Programmes. Teacher Education Programmes in Egypt

${ }^{29}$ Cohen et al., Research Methods in Education, 253-254.

${ }^{30}$ Christine Benedichte Meyer, “A Case in Case Study Methodology," Field Methods 13, $n^{\circ} 4$ (2001): 329-325.

${ }^{31}$ See: Robert K. Yin, Case Study Research: Design and Methods, 3rd ed. (London: SAGE, 2003) and Martyn Denscombe, The Good Research Guide: for small-scale social research projects, $3^{\text {rd }}$ ed. (Maidenhead: Open University Press, 2007). 
have gone through two major stages. The first stage started from early $19^{\text {th }}$ century till 1872, where there were no professional institutions in charge of Teacher Education Programmes. At this stage Arabic and Religion teachers used to come from Al-Azhar; Teachers of foreign languages, History and Geography used to come from Al-Alsun schools; Teachers of Art and Mathematics used to come from Al-Muhandisakhana Schools. Stage two which started from 1872 till present was marked with the advent of professional institutions in charge of Teacher Education Programmes. ${ }^{32}$

During that stage several institutions, under different titles, were established including: "Central Teachers' School" in 1880 for primary school teachers; "Khediwi Teachers' Schools" in 1905, which was renamed "Sultan Teacher's Schools" in 1915; "Teachers' High Institute" in 1922, for secondary and middle school teachers. In 1929, "Teachers' High Institute" was replaced with "Teachers' Institute of Education", which was a two year programme for graduates from Faculties of Arts and Sciences who would like to work as teachers. This institute has opened two new departments, one for Arts and the other for Physical Education. In 1954, the first "Teachers' College" was established in Cairo, which was later renamed "Faculty of Education" in 1965 and was affiliated to Ain Shams University. In 1970, all institutes and colleges of Teacher Education in Egypt were given the title of "Faculties of Education". Since then, several Faculties of Education were established in Egypt reaching 28 faculties affiliated to all Twenty Egyptian public Universities. ${ }^{33}$

Alexandria University is the second oldest university in Egypt after Cairo University. In 1938, the nucleus of Alexandria University (formerly known as Farouk University) had its beginning in the form of two faculties: Arts and Law. In the light of the need for developing more disciplines for higher learning and with a view to meeting the needs of the people of Alexandria, Alexandria University became a separate entity in August 1942 with four additional faculties: Science, Commerce, Medicine and Agriculture. In 1952, it became "Alexandria University". Since then, the University has witnessed growth and expansion in several fields with its number of faculties

${ }^{32}$ See: Hassan Elfeki, The Cultural History of Education in Egypt, $2^{\text {nd }}$ ed. (Cairo: Daar Al-Maarif, 1971) and Saeed Ismail Ali and Zeinab Hassan, Developing First Stage Teachers' Programme in Egypt (Cairo: Daar Al-Thaqafah, 1983).

${ }^{33}$ See: Ahmed H. Ebaid, Philosophy of the Educational System and Its Political Background (Cairo: Al-Anglo Al-Misreyah, 1979); Arfaat Abdelaziz Soliman, Teacher and Education (Cairo: Al-Anglo Al-Misreyah, 1991); Saeed Ismail Ali, The History of Education in Egypt (Cairo: Aalam Al-Kutob, 1985); and Ahmed Ismail Heggi, Developing Faculties of Education and Teacher Education Programmes in Australia, Asian and African Countries: Methodological Perspectives and Applied Methods (Cairo: Aalam Al-Kutob, 2011). 
and higher education institutes now numbering twenty-two. In 2012, Alexandria University won the award of excellence in scientific publishing from the Continuous Improvement and Qualifying for Accreditation Project of Egypt's Ministry of Higher Education.

There are three faculties in charge of Teacher Education at Alexandria University: Faculty of Education, Faculty of Kindergarten and Faculty of Specific Education. Alexandria University's Faculty of Education is the third oldest institution in Egypt among twenty-eight faculties affiliated to Egypt's twenty universities. The Faculty of Education consists of fourteen departments: seven for educational sciences, three for the basic sciences, three for linguistic sciences, and one for social sciences. It offers three different programmes leading to five different degrees. Teacher Education Programmes in Faculty of Education, Alexandria University, go into two tracks: the undergraduate level (the Integrated System) and the graduate level (the Consecutive System).

\section{The undergraduate level (the Integrated System):}

- The General Programme (for secondary school teachers): Graduates of this programme obtain the degree of B.A. \& Education in: Arabic English - French - Social Sciences; B.Sc. \& Education in: Mathematics - Physics and chemistry - Biology and Geology.

- The Basic Education Programme (for primary and middle school teachers): Graduates of this programme obtain the degree of $B . A$. in Basic Education in: Arabic - English - Social Studies; B.Sc. in Basic Education in: Mathematics - Sciences.

- The Childhood Education Programme (for Kindergarten teachers): Graduates of this programme obtain the degree of B.A. in Childhood Education.

\section{The graduate level (the Consecutive System):}

This is a one-year programme for graduates from Faculties of Arts and Sciences, who would like to work as teachers. Graduates of this programme are awarded the degree of "General Diploma in Education". They are eligible to teach in both middle and secondary schools. ${ }^{34}$

The Faculty of Kindergarten and Faculty of Specific Education were established in 1988 and joined Alexandria University with the Republican

${ }^{34}$ Madiba et al., “Teacher Education,” 322-323. 
decision no.389 in 1998. The period of study is 4 years. The Faculty of Kindergarten consists of three departments: Basic Sciences; Psychological Sciences and Educational Sciences. It offers one programme (for Kindergarten teachers). Graduates of this programme obtain the degree of B.A. in Childhood Education.

The Faculty of Specific Education consists of five departments: Home Economics; Art Education; Educational and Psychological Sciences; Music Education and Education Technology. It offers four programmes (for Specific Education teachers). Graduates of this programme obtain the degree of B.A. in Specific Education in: Home Economics - Art Education Music Education - Education Technology. ${ }^{35}$

\subsection{Sampling}

Non-probability sampling was adopted as the researcher has deliberately chosen three faculties in charge of Teacher Education at Alexandria University: Faculty of Education, Faculty of Kindergarten and Faculty of Specific Education which are not representative of the overall population of higher education in Egypt. This choice is due to several reasons: (a) the researcher has chosen Alexandria University because access to staff, students, recent graduates and employers is easier as he is an assistant professor at the University; (b) Alexandria University is the second oldest university in Egypt after Cairo University; (c) expense and time are limited for one researcher doing such a large scale research; (d) non-probability sampling is suitable for case studies as they do not aim to generalize findings to the whole population; (e) purposive sampling has also been used to access students in the latter years of their degree programme and recent graduates who graduated within the last 3 to 5 years.

The initial plan was to investigate the perceptions of around 360 stakeholders of the three selected faculties divided into four categories: 90 academics; 90 students; 90 recent graduates and 90 employers, who employ graduates of those three faculties. However, the study ended up with investigating the perceptions of 384 stakeholders: 71 academics; 137 students; 85 recent graduates and 91 academics. The number of academics was minimized from 90 to 71 as the total number of academics in Faculty of Kindergarten and Faculty of Specific Education is 33 and 36

35 Alexandria University, "Faculties \& Institutes," (2009-2015), accessed May 11, 2015, http://www.alexu.edu.eg/index.php/en/2015-11-24-10-39-04/faculties-institutes. 
respectively. The number of recent graduates was minimized from 90 to 85 as 5 questionnaires have been excluded because of missing data. The number of students was expanded from 90 to 137 to enable the researcher to cover students from the different programmes provided at Faculty of Education.

A mixed sample of academics, students, graduates and employers was approached for two main reasons. Firstly, to avoid a methodological problem identified by Stensaker ${ }^{36}$ and $\mathrm{Kis}^{37}$ concerning the possibility of academics having an interest in creating a successful image of the programmes provided at their faculties to show a good impression of their own effort. Secondly, having a mixed sample allows for triangulating the data through comparing the perceptions of participants on issues under investigation.

\subsection{Generalisability}

The extent to which the findings of this study can be applied to people or settings more widely may be questionable. Its main limitation is its limited ability to make generalizations, owing to non-probability sampling. While the purpose of 'generalization' is attached to the logic and power of probability sampling, 'in-depth understanding' is attached to nonprobability sampling. ${ }^{38}$ According to Patton, the proposals of this study could be implemented only at Alexandria University as the case included in the study.

However, the researcher argues that generalisation of the findings to the other 19 public universities in Egypt is feasible as there are many similarities between Alexandria University and Egypt's other universities. They are all funded publicly, follow the regulations of the Supreme Council for Universities (SCU) and have been subject to the same reforms of quality assurance. Moreover, the legislative framework for finance, governance and quality management is the same for all public universities. So, Alexandria

${ }^{36}$ Bjrn Stensaker, "Trance, Transparency and Transformation: the impact of external quality monitoring on higher education," Quality in Higher Education 9, n⿳0 2 (2003): 151-159.

37 Viktoria Kis, "Quality Assurance in Tertiary Education: Current Practices in OECD Countries and a Literature Review on Potential Effects" (paper presented as a contribution to the OECD Thematic Review of Tertiary Education, 2005), accessed July, 1 2012, http://www. oecd.org/dataoecd/55/30/38006910.pdf.

${ }_{38}$ Michael Quinn Patton, Qualitative Research \& Evaluation Methods. $3^{\text {rd }}$ ed. (Thousand Oaks: Sage Publications, 2002). 
University might be a "typical case", as proposed in ${ }^{39}$ with similarities that warrant such generalisations.

\section{VI.3. Data collection methods}

Questionnaires and semi-structured interviews have been used as the principal methods of data collection. The study has used triangulation of different methods to map out or explain more fully, the richness and complexity of human behaviour. The aim is to study phenomena from more than one standpoint as a way of gaining different insights into the same situation.

\subsection{Questionnaires}

As stated earlier, the current study has used the same questionnaire for Generic Competences and Subject-specific ones future teachers should be acquainted with, which was developed in Tuning Africa Project - I. Different stakeholders of the three selected faculties at Alexandria University were consulted on the degree of importance of those competences to future teachers and the level of achievement of the competences as a result of having completed a university degree.

Although 'It is impossible for research to be $100 \%$ valid; that is the optimism of perfection' ${ }^{40}$ precautions have been taken to secure different aspects of validity. Content validity is demonstrated through a careful process of piloting and re-piloting the questionnaire in Tuning Africa Project - I. This has increased validity by making sure that the instrument measured what it purported to measure. Construct validity is demonstrated through triangulation, which involved the use of a twofold method for data collection to enhance rigour: questionnaires and semi-structured interviews. Moreover, it combined quantitative and qualitative data. The multi-method approach adopted increased the validity or search for truth of the research and also helped overcome the problem of method-boundedness. Internal validity is demonstrated through ensuring that the findings were drawn from the data and accurately described the phenomena under investigation. External validity is demonstrated through the choice of Alexandria University as 'a typical case study' which has similarities

39 Martyn Denscombe, Ground Rules for Good Research: a 10 point guide for social researchers (Buckingham: Open University Press, 2002).

${ }^{40}$ Cohen et al., Research Methods in Education, 133. 
with the other cases that warrant generalisations to the other public universities in Egypt. ${ }^{41}$ The questionnaire has been translated into Arabic so that it could be applied in Egypt. The translated version of the questionnaire has been revised by experts in the field and the required changes were done before the field work.

\subsection{Semi-structured interviews}

Semi-structured interviews were conducted with 10 academics, from Educational Sciences departments, from Faculty of Education as it is the third oldest Faculty of Education in Egypt and has experts in all fields of education. They have been used as a secondary method of data collection. Although the researcher using this technique has some established topics (questions) for investigation, the method allows for exploring emergent themes and ideas. The researcher used a standardized schedule but was free to pursue and probe for novel and relevant information through additional questions. ${ }^{42}$

Those interviews were conducted with academics directly after responding to the questionnaire. The interview schedule was brief and mainly included the following questions:

1. Are Teacher Education Programmes at Alexandria University compatible with competence-based learning?

2. To what extent do they cover both generic competences and subjectspecific ones included in the questionnaire?

3. Are those competences included in the questionnaire fair enough for future teachers?

4. Are the intended learning outcomes of the available programmes measurable? If yes, do they get measured?

5. Is there any similarity between the content of the available programmes and the list of competences in the questionnaire?

6. Would you like to add any competences to the available list of competences?

7. Is there a possibility of reforming the system by including such competences in the curriculum design, student assessment and evaluation systems?

41 Ibid.

${ }^{42}$ Hilary Arksey and Peter T. Knight, Interviewing for Social Scientists (London: Sage Publications, 1999). 
After transcribing the data, it has been organized it into retrievable sections. Each interview has a number and a code and given interviewees pseudonyms (AS: Academic Staff) with a file which helped link pseudonyms to the original informants (e.g. AS10: means Academic Staff number10).

\section{Findings and discussion}

The main findings show that, across all different stakeholders, there are significant gaps between what is deemed important and what is deemed as the level of achievement for both generic and subject-specific competences. The average ranking for all generic competences in terms of importance was 3.72 but achievement was 2.51 . In addition, the average ranking for all Subject-specific competences in terms of importance was 3.78 whereas achievement was 2.57. This finding implies that Teacher Education Programmes at Alexandria University have gaps in instructional service delivery. This is an indication that effort and intentional strategies need to be put in place to minimise the gaps of Teacher Education Programmes at Alexandria University.

This section starts by discussing and analyzing the key findings generated from questionnaires (quantitative data), followed by discussing and analyzing the key findings generated from semi-structured interviews (qualitative data).

\section{VII.1. Quantitative Data}

Concerning the first research question "What are the perceptions of different stakeholders of Alexandria University on the generic competences which future teachers should be acquainted with?", the findings came as follows.

For the generic competences, it was interesting to note that "professionalism, ethical values and commitment to Ubonto" (\#2) was ranked the most important competence across all groups except for graduates where "ability for creative and innovative thinking" (\#10) was considered the highest important, followed by (\#2).

On the other hand, "environmental and economic consciousness" (\#13) and "ability to work in an intra and intercultural and/or international context" (\#14) were ranked the least important competences by all groups. Figure 2 shows importance ratings across all groups and Table 3 shows the highest and lowest generic competence in terms of importance across all groups. 


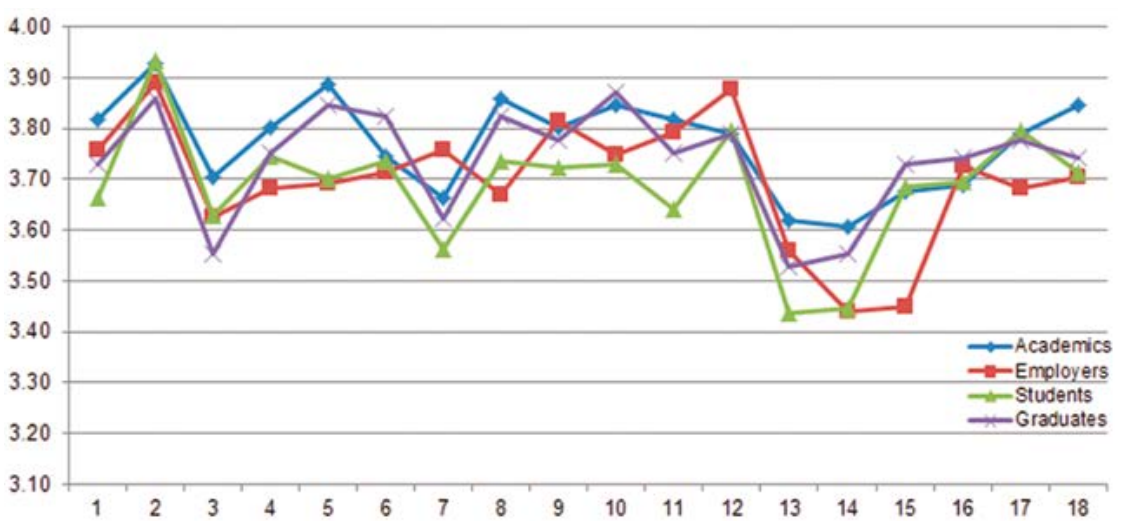

Figure 2

Generic Competences' Importance Ratings across All Groups

Table 3

The Highest and Lowest Generic Competence in Terms of Importance

\begin{tabular}{|l|c|c|}
\cline { 2 - 3 } \multicolumn{1}{c|}{} & Highest & Lowest \\
\hline Academics & 2 & 14 \\
\hline Employers & 2 & 14 \\
\hline Students & 2 & 13 \\
\hline Graduates & 10 & 13 \\
\hline
\end{tabular}

This finding corresponds with findings on the generic competences of Tuning Africa Project - I where the generic competence (\#2) was placed in the top five most important competences and the generic competence (\#13) was ranked among the least important competences by all groups. ${ }^{43}$

In terms of achievement, the generic competences "communication and interpersonal skills" (\#12) and "professionalism, ethical values and commitment to Ubuntu" and (\#2) were perceived to be the highest achieved generic competences by all groups. Academics perceived "ability to communicate effectively in official/national and local language (\#7) to be the

${ }^{43}$ Madiba et al., "Teacher Education," 354. 
highest achieved generic competence. On the other hand, "ability to work in an intra and intercultural and/or international context" (\#14) and "selfconfidence, entrepreneurial spirit and skills" (\#17) were perceived to be the least achieved competences by all groups. Figure 3 shows achievement ratings across all groups and Table 4 shows the highest and lowest generic competence in terms of achievement.

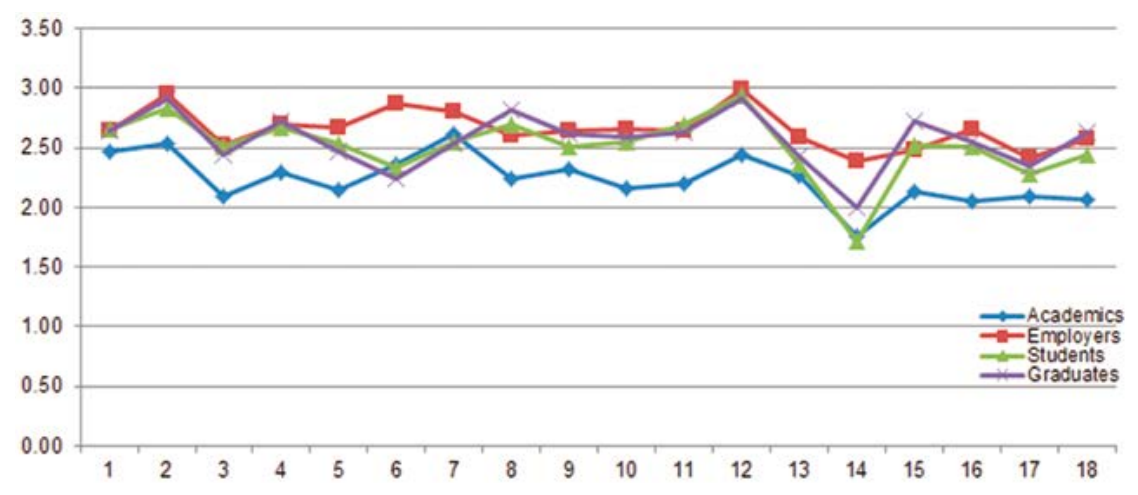

Figure 3

Generic Competences' Achievement Ratings across All Groups

Table 4

The Highest and Lowest Generic Competence in Terms of Achievement

\begin{tabular}{|l|c|c|}
\cline { 2 - 3 } \multicolumn{1}{c|}{} & Highest & Lowest \\
\hline Academics & 7 & 14 \\
\hline Employers & 12 & 14 \\
\hline Students & 12 & 14 \\
\hline Graduates & 12 & 14 \\
\hline
\end{tabular}

The above results imply that the perceptions of academics, employers, students and graduates were similar both in terms of which generic competences were the most important and how successfully they were achieved during Teacher Education Programmes at Alexandria University. Interestingly, this was the same case among all groups in Tuning Africa 
Project - I. This finding therefore validates the findings of Tuning Africa Project - I.

Concerning the second research question "What are the perceptions of different stakeholders of Alexandria University on the subject-specific competences which future teachers should be acquainted with?", the findings came as follows.

As for the subject-specific competences, it was interesting to note that "maintain equity and fairness among learners and promote inclusive education" (\#24), "continuously upgrade their own knowledge and skills" (\#25), "be a role model" (\#26), "develop schemes of work and teaching plans" (\#7) and "select, adopt and use appropriate teaching methods and learning activities" (\#8) were ranked among the most important competences across all groups. What is remarkable about this finding is the general agreement across all groups on five competences three of which are related to values and ethics of the teaching profession (\#24, \#25 and \#26) and two of them (\#7 and \#8) are related to educational practice and skills.

On the other hand, it was notable that "the local and international social, political, economic, cultural and environmental contexts of education" (\#4), "national and institutional policies relating to education" (\#5), "develop own and learners' entrepreneurial skills" (\#13) and "participate in basic educational research" (\#17) were ranked among the least important competences across all groups. Figure 4 shows importance ratings across all groups and Table 5 shows the highest and lowest subject-specific competence in terms importance across all groups.

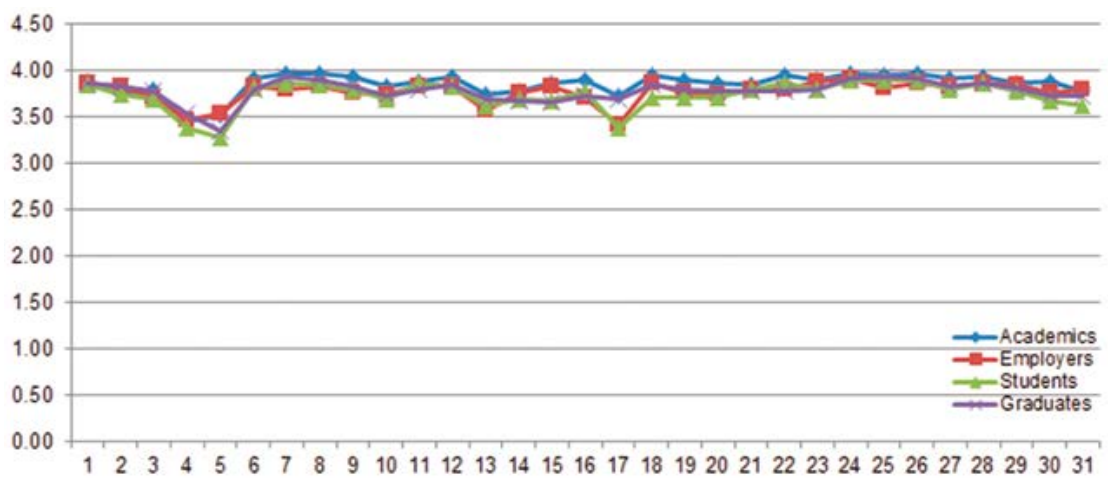

Figure 4

Subject-specific Competences' Importance Ratings across All Groups 
Table 5

The Highest and Lowest Subject-specific Competence in Terms of Importance

\begin{tabular}{|l|c|c|}
\cline { 2 - 3 } \multicolumn{1}{c|}{} & Highest & Lowest \\
\hline Academics & 7 & 4 \\
\hline Employers & 24 & 17 \\
\hline Students & 24 & 5 \\
\hline Graduates & 7 & 5 \\
\hline
\end{tabular}

This finding corresponds with findings on the subject-specific competences of Tuning Africa Project - I where the competences (\#4 and \#13) were placed among the least important competences by all groups. ${ }^{44} \mathrm{On}$ the other hand, in terms of the highest important competences, the findings from this study do not go in line with findings of Tuning Africa Project - I where the competences "The subjects to be taught" (\#1) and "The language(s) of instruction" (\#6) were ranked among the most important competences by all groups.

In terms of achievement, it was exciting to note that "the subject(s) to be taught" (\#1), "the underlying principles of the foundations of education" (\#2), "develop schemes of work and teaching plans" (\#7) and "select, adapt and use appropriate teaching methods and learning activities" (\#8) were ranked among the highest achieved subject-specific competences across all groups.

On the other hand, it was notable that "the local and international social, political, economic, cultural and environmental contexts of education" (\#4), "national and institutional policies relating to education" (\#5), "develop own and learners' entrepreneurial skills" (\#13) and "participate in basic educational research" (\#17) were ranked among the least achieved competences across all groups. Figure 5 shows achievement ratings across all groups and Table 6 shows the highest and lowest subject-specific competence in terms achievement across all groups.

44 Ibid. 


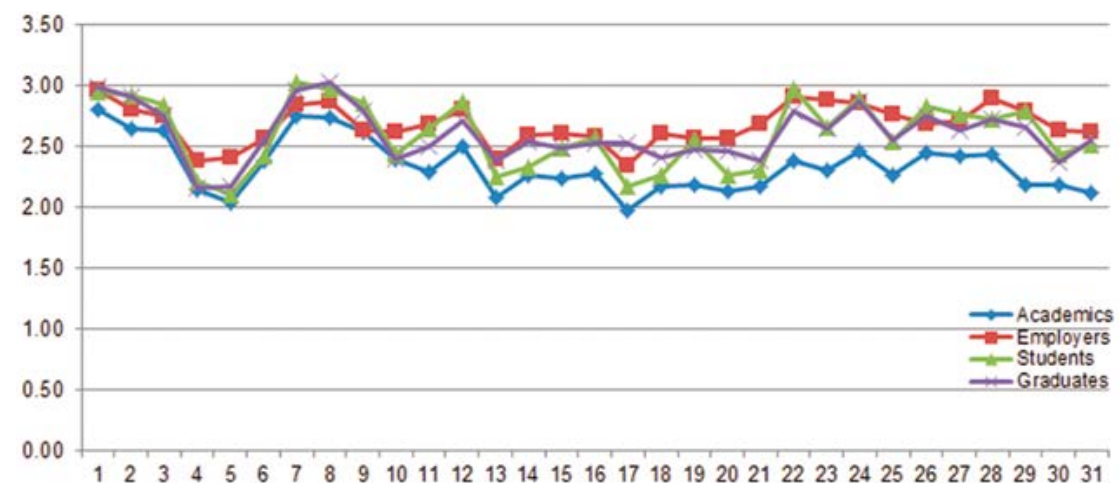

Figure 5

Subject-specific Competences' Achievement Ratings across All Groups

\section{Table 6}

The Highest and Lowest Subject-specific Competence in Terms of Achievement

\begin{tabular}{|l|c|c|}
\cline { 2 - 3 } \multicolumn{1}{c|}{} & Highest & Lowest \\
\hline Academics & 1 & 17 \\
\hline Employers & 1 & 17 \\
\hline Students & 7 & 5 \\
\hline Graduates & 8 & 4 \\
\hline
\end{tabular}

This finding corresponds with part of the findings on the subject-specific competences of Tuning Africa Project - I where the competences (\#1 and \#6) were placed among the most achieved competences by all groups. In terms of the least achieved competences in Teacher Education Programmes, the findings of this study correspond with findings of Tuning Africa Project - I where the competence (\#13) was ranked among the least achieved competences across all groups. This finding also corresponds with employer studies from Ghana, Senegal, Egypt, Namibia, Botswana, and South Africa all stress a serious problem with skills gaps, noting gaps in the basic skills and entrepreneurial skills of young people. ${ }^{45}$

45 Monika Aring, "Paper commissioned for the EFA Global Monitoring Report 2012, Youth and skills: Putting education to work" (UNESCO, 2012). 
The above results imply that the perceptions of academics, employers, students and graduates were similar both in terms of which subject-specific competences were the most important and how successfully they were achieved during Teacher Education Programmes at Alexandria University. Interestingly, this was the same case among all groups in Tuning Africa Project - I. This finding thus validates the findings of Tuning Africa Project $-\mathrm{I}$.

\section{VII.2. Qualitative Data}

After responding to the questionnaire on both generic competences and subject-specific ones future teachers should be acquainted with, ten academics were interviewed with a view to an analysis of the context and processes involved in the phenomenon under study. The selected cases have enabled the researcher to develop detailed knowledge of the experience of participants on Teacher Education Programmes at Alexandria University and an examination of the strengths and weaknesses of existing systems, leading to an identification of implications for policy and practice for enhancing the quality of Teacher Education Programmes in Egyptian higher education.

As stated earlier, the interview schedule was mainly comprised of seven questions. Concerning the first question: "Are Teacher Education Programmes at Alexandria University compatible with competence-based learning?". There was a general agreement among interviewees that Teacher Education Programmes at Alexandria University are not compatible with competence-based learning. They added that the vision behind those programmes is vague as was put in the words of one of the interviewees "A complete absence of paradigm" (AS, 2). It is not even based on tracks where each track has its own philosophy and methodology. One of the interviewees added that the current programmes are inheritance of old regulations which were based on the regulations of Faculties of Arts and Science where academic subjects were taught with a light dose of educational subjects. This light dose of Educational subjects has been expended in the eighties and nineties before going back to its normal size (20\% of the taught subjects) through Faculties of Education Project (FoEP) in 2003 (AS, 1).

Thus, Teacher Education Programmes at Alexandria University are not competence-based as they are not built according to a plan of what is expected of the graduate or the competences which s/he should be acquainted with. Another reported issue which is totally against competence-based learning approach is that the $20 \%$ allocated for educational subjects is 
divided equally among Educational departments regardless of the graduate's needs, which again confirms that the vision behind those programmes is vague. For example, "There are some subjects from Comparative Education Department which should be taught in postgraduate programmes but actually they are taught in undergraduate programmes just because it's their share of the $20 \%$ allocated for Educational Departments" (AS, 2). However, the way this $20 \%$ is divided should be based on the graduate's needs.

As for the second question: "To what extent do they cover both generic competences and subject-specific competences included in the questionnaire?", they agreed that the level to which generic competences are developed through Teacher Education Programmes at Alexandria University are between (1) none and (2) weak as the development of such competences depends mainly on academics although it should be covered in all modules. On the other hand, they perceive that the level to which most subject-specific competences are developed through Teacher Education Programmes are between (2) weak and (3) moderate. One of the interviewees added that:

The importance for most of the generic and subject-specific competences included in the questionnaire stands at (4) strong whereas the level of achievement for most of them will not exceed (2) weak or (3) moderate. This means that students in Teacher Education Programmes are not provided with the content, teaching methods, learning chances or assessment which provides them with authentic sustainable learning which makes them professional teachers in the future. This mainly goes back to the fact that most of the teaching methods used are based on indoctrination and most exams measure the students' ability to recall what they have learnt. (AS, 2)

In regard to the third question: "Are those competences included in the questionnaire fair enough for future teachers?", they agreed that the lists of generic and subject-specific competences included in the questionnaire are more than fair enough for future teachers to be acquainted with and they wished that they could be covered in Teacher Education Programmes.

Concerning the fourth question: "Are the intended learning outcomes of the available programmes measurable? If yes, do they get measured?" They agreed that every programme has general aims which are translated into specific objectives for each module in the programme. Each module has those specific objectives or intended learning outcomes (ILOs) which are measurable but they do not get measured properly as student assessment systems measures the content of the module rather than its ILOs. It is reported that "Most exams assess students' ability to recall parts of the content. It is as if students are asked to re-vomit what they know about the 
content" (AS, 7). Another interviewee added that "When academics update the syllabus by changing some parts of the content, student assessment systems still measures the content not the general ILOs of the module or the subject being taught" (AS, 5). The same point was confirmed by another interviewee stating that "Teacher Education Programmes are staff-centered instead of student-centered. In other words, it is based on teaching and do not maximize the students' chances of learning" (AS, 8).

As for the fifth question: "Is there any similarity between the content of the available programmes and the list of competences included in the questionnaire?". They agreed that there is a similarity between the available programmes and the lists of competences especially for subject-specific competences most of which are covered between (2) weak and (3) moderate. However, the list of generic competences is not covered well in the content of the available programmes. It was added that some existing course structures in Teacher Education Programmes can incorporate the identified lists of competences whereas others lack that ability given their current structures, staff perspectives and regulations.

Concerning the sixth question: "Would you like to add any competences to the available list of competences?". Two interviewees (AS, 2 and AS, 9) added the competence of "Good command of English as a second language" which they perceived to be so important for students' lifelong learning and professional development.

In regard to the last question: "Is there a possibility of reforming the system by including such competences in the curriculum design, student assessment and evaluation systems?" There was a general agreement that there is a big possibility of reforming the system as most of the specificcompetences are already covered in the available programmes but the level of achievement is weak or moderate. However, those competences need to be included in the curriculum design, student assessment and evaluation systems, which means a paradigm shift from input and staff-centered programmes to output and student-centered ones. For that paradigm shift to be achieved regulations of the available programmes need to be changed and the chance for this change happens once every five years. Second, awareness about the importance of competences and competence-based learning should be raised among all education stakeholders among which are students and academics. Such awareness will help in overcoming resistance for change. Third, different stakeholders - academics - students - graduates and employers - should be involved at certain stages of curriculum development and design. Last, but not least, the number of hours allocated for each programme should not be divided equally among different departments, they 
should, instead, be divided among different departments according to graduates' actual needs.

\section{Concluding remarks}

The average ranking for all competences was 3.75 but achievement was 2.54. This finding implies that Teacher Education Programmes at Alexandria University have gaps in instructional service delivery. The mean for achievement is always lower than the mean for importance. This is no surprise as this is the case in all other previous Tuning studies, and most studies using this double scale of 'importance' and 'achievement' show similar results.

It is worth noting that respondents across all groups singled out the following generic competences as poorly achieved: "ability to work in an intra and intercultural and/or international context" (\#14) and "selfconfidence, entrepreneurial spirit and skills" (\#17). They also singled out the following subject-specific competences as poorly achieved: "the local and international social, political, economic, cultural and environmental contexts of education" (\#4), "national and institutional policies relating to education" (\#5), "develop own and learners' entrepreneurial skills" (\#13) and "participate in basic educational research" (\#17). Yet, these are some of the most important competences teachers should be acquainted with.

It is also worth noting that respondents across all groups singled out the following generic competences as the least important ones: "environmental and economic consciousness" (\#13) and "ability to work in an intra and intercultural and/or international context" (\#14). They also singled out the following subject-specific competences as the least important ones: "the local and international social, political, economic, cultural and environmental contexts of education" (\#4), "national and institutional policies relating to education" (\#5), "develop own and learners" entrepreneurial skills" (\#13) and "participate in basic educational research" (\#17). The most striking revelation in the findings is that academics rate "develop one's own and learners' entrepreneurial skills" (\#13) and "ability to participate in basic educational research" (\#17) as both of least importance and least successfully achieved. This implies that academics themselves are not keen on helping future teachers to be acquainted with such crucial competences.

It is worth noting that, across all the different groups, there are significant gaps between what is deemed important and what is deemed as the level of achievement for both generic and subject-specific competences. This is an 
indication that effort and intentional strategies need to be put in place to minimise the gaps.

Semi-structured interviews have enabled the researcher to develop detailed knowledge of the experience of participants on Teacher Education Programmes at Alexandria University and an examination of the strengths and weaknesses of existing systems, leading to an identification of implications for policy and practice for enhancing the quality of Teacher Education Programmes in Egyptian higher education.

\section{The way ahead: implications for policy and practice}

This section addresses the third research question: What are the proposed implications - according to study findings - for policy and practice to enhance the quality of Teacher Education Programmes in Egyptian higher education?

Based on the analysis and discussion of key findings of the study and through the insights from a comparative perspective that can arise from a careful process of policy learning, this section draws out their emergent implications for policy and practice to enhance the quality of Teacher Education Programmes in Egyptian higher education.

The theoretical framework and the key findings of the study confirmed the importance of competence-based learning and the importance of generic competences and subject-specific ones future teachers should be acquainted with. Those competences need to be included in the curriculum design, student assessment and evaluation systems in Teacher Education Programmes at Alexandria University to enhance degree comparability, graduate mobility with other African universities and employability. This means a paradigm shift from input and staff-centered programmes to output and student oriented ones. For that paradigm shift to be achieved, several implications for policy and practice should be addressed:

- Regulations of the available programmes need to be changed and adapted to allow the inclusion of those generic competences and subject-specific ones future teachers should be acquainted with in curriculum design, student assessment and evaluation systems. The chance for changing regulations of programmes normally happens once every five academic years. A report of the findings of the current study is to be sent to the University Council, the committees in charge of regulations and to the Faculty Council of the three faculties involved in the study to be considered properly before reforming regulations. 
- Several conferences and workshops should be held to raise awareness about the importance of competences and competence-based learning for academics, students, graduates, employers and for the society at large.

- All stakeholders including academics, students, graduates, potential employers and professional organizations should be indirectly involved at different stages in the process of curriculum design and quality enhancement.

- To achieve those proposals, attention should be given to staff development and training. Thus, the study proposes a project on capacity building and training for academics in the three faculties involved in the study to enable them to incorporate new competences in the existing programme/course structures. Training package should cover the processes of curriculum design, student assessment and evaluation systems.

- In addition to the importance of restructuring the existing programme/ course structures to provide space for incorporating new competences future teachers should be acquainted with, new courses with structures that can incorporate necessary competences should be initiated, for the sake of realizing the harmonisation target.

- On the long run, changing regulations, raising awareness about the importance of competence-based learning and capacity building and training for academics will facilitate designing common curriculum development frameworks to enable comparability and equivalence of learning outcomes between Alexandria University and other African universities.

Last, but not least, the proposed implications for Policy and Practice provided for the researcher's own university might be of relevance for other public universities in Egypt and for other countries having similar education context. Finally, working according to a new paradigm or coping with a new paradigm requires time and effort but the outcome would be worthwhile, hopefully in respect of enhancing the quality of Teacher Education Programmes in Egyptian higher education.

\section{Bibliography}

"Joint Africa-EU Strategy Tuning Seminars, Second General Meeting." Cape Town, 15-17 May 2012. Accessed May 11, 2015, http://www.tuningafrica.org/images/ stories/documentos/documento_cape_town_ingles_final_para_colgar_final.pdf 
“Tuning Academy Brochure." http://tuningacademy.org/wp-content/uploads/2015/ 01/Tuning_Academy_brochure.pdf

“Tuning Academy". http://tuningacademy.org/tuning-projects

Alexandria University. "Faculties \& Institutes." (2009-2015). Accessed May 11, 2015. http://www.alexu.edu.eg/index.php/en/2015-11-24-10-39-04/facultiesinstitutes.

Ali, Ismail Saeed and Hassan, Zeinab. Developing First Stage Teachers' Programme in Egypt. Cairo: Daar Al-Thaqafah, 1983.

Ali, Ismail Saeed. The History of Education in Egypt. Cairo: Aalam Al-Kutob, 1985.

Alshamy, Alsaeed. Quality, Finance and Governance in Egyptian Higher Education: A Comparative Analysis. Berlin: LAP Lambert Academic Publishing, 2013.

Amin, Ghada. "Egypt Country Report: Policies and Mechanisms for Integration into the Workforce and Job Creation." Paper presented at the 2014 Ministerial Conference on Youth Employment: How to Improve, through Skills Development and Job Creation, Access to Africa's Youth to the World of Work, Abidjan, Côte d'Ivoire, July 21-23, 2014.

Aring, Monika. "Paper commissioned for the EFA Global Monitoring Report 2012, Youth and skills: Putting education to work." UNESCO, 2012.

Arksey, Hilary and Knight, T. Peter. Interviewing for Social Scientists. London: Sage Publications, 1999.

Berlin Communiqué. "Realising the European Higher Education Area”. Communiqué of the Conference of Ministers responsible for Higher Education. Berlin, 2003. Accessed May 11, 2015, http://www.ehea.info/Uploads/Declarations/Berlin_ Communique1.pdf.

The European Higher Education Area. "The Bologna Declaration of 19 June 1999: Joint declaration of the European Ministers of Education." 1999. Accessed May 11, 2015, http://www.ehea.info/Uploads/Declarations/BOLOGNA_ DECLARATION1.pdf.

Book, A. Patricia. "All Hands on Deck: Ten Lessons from Early Adopters of Competency-Based Education”. Boulder, CO: WICHE Cooperative for Educational Technologies (WCET), 2014.

Central Agency for Public Mobilization and Statistics (CAPMAS). Egypt Statistical Yearbook 2015. Cairo: CAPMAS, 2015.

Chakroun, Borhene. "What can we learn from policy learning?." In Yearbook 2008. Policy Learning in Action, 11-18. Turin: European Training Foundation, 2008.

Cohen, Louis., Lawrence Manion and Keith Morrison. Research Methods in Education. $6^{\text {th }}$ edition. London: Routledge, 2007.

Denscombe, Martyn. Ground Rules for Good Research: a 10 point guide for social researchers. Buckingham: Open University Press, 2002.

- The Good Research Guide: for small-scale social research projects. $3^{\text {rd }}$ edition. Maidenhead: Open University Press, 2007.

Denzin, K. Norman. and Lincoln, S. Yvonna. Handbook of Qualitative Research. London: Sage, 2002. 
Ebaid, H. Ahmed. Philosophy of the Educational System and Its Political Background. Cairo: Al-Anglo Al-Misreyah, 1979.

Elfeki, Hassan. The Cultural History of Education in Egypt. $2^{\text {nd }}$ Edition. Cairo: Daar Al-Maarif, 1971.

Gonzalez, Julia. and Wagenaar, Robert. Tuning Educational Structures in Europe. Final Report: Pilot Project - Phase 1. Bilbao: University of Deusto, 2003.

- Tuning Educational Structures in Europe. Universities' Contribution to the Bologna Process. Final Report: Pilot Project - Phase 2. Bilbao: University of Deusto, 2005.

- Tuning Educational Structures in Europe. $2^{\text {nd }}$ edition. Bilbao: University of Deusto, 2008.

Hahn, Karola. and Teferra, Damtew. "Tuning as Instrument of Systematic Higher Education Reform and Quality Enhancement: The Africa Experience." Tuning Journal for Higher Education 1 (2013): 127-163.

Heggi, Ismail Ahmed. Developing Faculties of Education and Teacher Education Programmes in Australia, Asian and African Countries: Methodological Perspectives and Applied Methods. Cairo: Aalam Al-Kutob, 2011.

International Labour Organization. Global Employment Trends for Youth 2013: A Generation at Risk. GENEVA: ILO Cataloguing in Publication Data, 2013.

Kis, Viktoria. "Quality Assurance in Tertiary Education: Current Practices in OECD Countries and a Literature Review on Potential Effects." Paper presented as a contribution to the OECD Thematic Review of Tertiary Education, 2005. Accessed July, 1 2012, http://www.oecd.org/dataoecd/55/30/38006910.pdf.

Klein-Collins, Rebecca. "Competency-Based Degree Programs in The U.S.: Postsecondary Credentials for Measurable Student Learning and Performance." Council on Adult and Experiential Learning, 2012.

Mackenzie, Noella, and Sally Knipe. "Research Dilemmas: Paradigms, Methods and Methodology." Issues In Educational Research 16, n² (2006): 193-205.

Madiba, Matete, Eugenia Flora Rosa Cossa, Zubeida Khatoom Desai, Shaheed Hartley, Geressu Birhane Sime, Arlene Gilpin, Mohamed Hassan Noor, Babatunde Joseph Ipaye, Pauline Lyonga Lyonga, Therese MUNGAH SHALO EPSE TCHOMBE, Théophile MAGANGA, Rosemary MOYANA, Stanley Gathogo MUKURIA, Honoratha Michael Kisenge MUSHI, Mugagga Anthony MUWAGGA, Rotimi Joshua OGIDAN, Emmanuel Chukwugozie OSINEM, and Charmaine Benite VILLET. "Teacher Education." In Tuning and Harmonisation of Higher Education: The African Experience, edited by Onana, Awono Charles, Olusola Bandele Oyewole, Damtew Teferra, Pablo Beneitone, Julia Gonzalez, and Robert Wagenaar, 315-374. Spain: University of Deusto, 2014.

Meyer, Benedichte Christine. "A Case in Case Study Methodology." Field Methods 13, no 4 (2001): 329-325.

OECD. "Tertiary Education for the Knowledge Society: OECD Thematic Review of Tertiary Education: Synthesis Report.” 2008. Accessed April, 1 2014, http:// oecd-conference-teks.iscte.pt/downloads/OECD_overview.pdf. 
Patton, Quinn Michael. Qualitative Research \& Evaluation Methods. $3^{\text {rd }}$ edition. Thousand Oaks: Sage Publications, 2002.

Phillips, David and Schweisfurth, Michele. Comparative and International Education: An introduction to theory, method, and practice. $2^{\text {nd }}$ edition. London: Continuum International Publishing Group, 2008.

Raffe, David. Policy borrowing or policy learning? How (not) to improve education systems. Centre for Educational Sociology: The University of Edinburgh. CES Briefing, No.57, 2011.

Salama, Ezzat Amr. "Addressing the Challenges of the Education/Skills and Jobs Mismatch." Education partnerships and work skills on the menu at ECOSOC, Coordination Segment Pane II Issue Note. New York: 10-12 July, 2012. Accessed April, 1, 2014, http://www.un.org/en/ecosoc/julyhls/pdf12/un_ presentation-dr_amr_salama.pdf.

Sánchez, Villa Aurelio. and Ruiz, Poblete Manuel,.eds. Competence-based learning: A proposal for the assessment of generic competences. Bilbao: Deusto University Press, 2008.

Soliman, Abdelaziz Arfaat. Teacher and Education. Cairo: Al-Anglo Al-Misreyah, 1991.

Stensaker, Bjrn. "Trance, Transparency and Transformation: the impact of external quality monitoring on higher education." Quality in Higher Education 9, no 2 (2003): 151-159.

Wagenaar, Robert. "Competences and Learning Outcomes: a Panacea for Understanding the (New) Role of Higher Education?." Tuning Journal for Higher Education 1, $\mathrm{n}^{\circ} 2$ (2014): 127-163.

Yin, K. Robert. Case Study Research: Design and Methods. $3^{\text {rd }}$ edition. London: SAGE, 2003.

\section{About the Author}

SAEED ALSHAMY (saeed.alshamy@edu.alexu.edu.eg) is an assistant professor at Foundations of Education Department, Faculty of Education, Alexandria University, Egypt. He holds PGCE and PhD in Education from University of Birmingham (UK). His $\mathrm{PhD}$ dissertation mainly addresses global trends in funding mechanisms and quality assurance systems in higher education. His principal research interests include: educational policy, comparative and international education, funding mechanisms, quality assurance systems, assessment and evaluation in higher education, competence-based learning, educational research, educational leadership and change management. One of Dr. Alshamy's most recent publications is a book titled "Quality, Finance and Governance in Egyptian Higher Education: A Comparative Analysis". 


\title{
Teacher Education Programmes at Alexandria University with reference to Tuning Methodology
}

\author{
Alsaeed Alshamy
}

\section{Copyright}

Copyright for this article is retained by the Publisher. It is an Open Access material that is free for download, distribution, and or reuse in any medium only for non-commercial purposes; provided any applicable legislation is respected, the original work is properly cited, and any changes to the original are clearly indicated. 